\title{
Hedging feasibility perspectives against the COVID-19 in the international tourism sector
}

\author{
Angeliki, N. Menegaki, \\ i) Agricultural University of Athens, Department of Tourism Economics and \\ Management , Amfissa Campus, Greece, 33100, \\ Email: amenegaki@aua.gr, Tel:+30 6972/443546 \\ ii) Open University of Cyprus, Nicosia, Cyprus \\ iii) Hellenic Open University, Patras, Greece
}

\begin{abstract}
Nowadays tourism is growing as a gigantic, global business accounting for $10.4 \%$ of Global GDP and $10 \%$ of global employment (Joppe, 2020). This review paper aims to explore the risks borne for tourism sector by the outbreak of corona-virus in 2020 . Tourism sector is a highly vulnerable sector and the costs that will be borne from corona-virus pandemic will be devastating, particularly for the countries relying on this sector as a basic source of income. The paper suggests possible solutions and adaptation routes, while at the same time reviews lessons of the past from other pandemics and crisis. This paper is very useful for tourism policy makers and governments in countries where tourism contributes a significant part of their GDP, but also for other economic sectors closely but indirectly connected in the tourism value chain.
\end{abstract}

\section{Keywords: corona-virus; COVID-19; tourism sector; review; risk hedging;}

\section{Introduction}

Nowadays we live in an era of unprecedented fear of the corona-virus which constitutes a symmetrical threat for all humanity. The fear is even worse than a war or terrorist attack because it can reach every part of the Earth in an invisible and sneaky way. The threat is not asymmetrical, because everybody is exposed simultaneously to the same problem. Still, a lot of things about the origin and the reasons of the outbreak are unknown and thus extensive and thorough research is currently under way and will continue to do so, since according to scientists, the necessary time for the vaccine to be fabricated is at least 18 months. This entails that the atmosphere of fear and reservation will pertain for a long time, before our lives will resume their previous pace.

Undoubtedly, the effects on the economies, environment and societies are huge. This paper however will focus on tourism as a particularly vulnerable sector of the economy that will sadly come to a dead end for a long time and maybe corona-virus will signal a new era of envisaging a completely different form of tourism from what we used to know and practice up-to date.

Tourism is a globalized phenomenon. After the $2^{\text {nd }}$ world war, as people started regaining their psychological and economic balance, tourism has gradually evolved 
from a luxury good into a fundamental human right. The right for leisure, for relaxation, for experiencing something different from one's everyday routine. Tourism contains a dynamic element and a static one. The tourist moves to a destination and then stays on a destination or moves around it. Increased globalization entails that people get in huge aircrafts (or other means of public transport) in mass numbers and move to other places within one's country (domestic tourism) or outside one's country (international tourism). When they arrive at their destination, they stay in enormous hotels in hotel rooms that have been previously inhabited by other people and they share the same hotel facilities (breakfast and dinner lounges, sports and activities rooms etc) or they participate in organized trips and excursions whereto they travel with other tourists from their hotel or they meet more tourists in the places of attraction (museums, archaeological sites, beaches etc). Thus, in its majority of manifestations, tourism involves co-existence with other people of different nationalities and backgrounds. This framework entails that tourism as it occurs today is a perilous activity for health in cases of pandemic outbreaks such as the COVID19.

This paper first makes a brief historic overview of how tourism and has reacted in front of other pandemics (from an economic and social perspective), reviews the dimensions through which tourism is heavily afflicted by the COVID19 (as a significant part of the globalized economy) and suggests ways of adaptation in front of this extremely risky situation. Until the invention of the relevant vaccine and the effective therapy, apparently the only way out is protection and adaptation of economies, tourism sector included. This paper will be useful not only for policy making in tourism at local, regional, national and international level, but will also provide insights and best practice examples for other sectors and prepare for other health crisis in the future.

The rest of the paper is outlined as follows: After this brief introduction (part 1), follows part 2 which is a historic review of other health crises and pandemic outbreaks and their effects on tourism. Also this section provides a short account about the COVID-19 chronicle. Part 3 provides an overview of all the dimensions through which COVID-19 impacts the economies and most specifically the tourism sector. Part 4 describes a collection of adaptation scenarios that can improve the situation in tourism and transform it into a sector resilient to these perilous circumstances. Last, part 5 concludes the paper and provides insights for further research.

\section{A historic overview of the impact of health crises and pandemic outbreaks on tourism in the last two decades}

The Spanish flu occurred in 1918-1920 killing 50 million people in 6 months time. According to Jonung and Roeger (2006) the Spanish flu led to a loss of only $1.6 \%$ of GDP in its incidence year. Since tourism was not a massive phenomenon at that time, that case is not comparable to other more recent outbreaks such as the ones referred to below in this section. Therefore this section will not refer to much older pandemic outbreaks from the Spanish flu and backwards. The paper will provide an 
overview from outbreaks occurring from the 1960s and afterwards, when tourism took its first steps as a more massive phenomenon. Thus the rest of this section consists of ten shorter sub-section, each providing a brief overview of a disease outbreak and its effects on tourism or the wider economy. In parenthesis are the year dates of occurrence from older to most recent.

\subsection{Malaria $(1969,1975,1998)$}

Malaria is a mosquito borne disease which killed 405,000 people in 2018 (Center for Disease Control and Prevention, 2020). If affects mostly children and pregnant women. The disease had been eliminated in Mauritius in 1969. Then it reappeared in 1975 and was eliminated for a second time in 1998. It is also an illness found in subSaharan countries as well as Morocco, Oman and the Arab Emirates, Asia and Latin America, namely countries than are located within a broad band around the Equator. The study my Modrek et al. (2012) has found only a weak relationship between tourism arrivals and malaria cases in two countries with tourism sectors of significant size: Mauritius and Dominican Republic. The study on Mauritius examined yearly tourist arrivals and malaria cases from 1978-1999. The study on Dominican Republic investigates monthly tourist arrivals from 1998-2000 to study whether reduction in tourist arrivals are a result of malaria outbreaks. Mauritius has implemented a passenger screening programme which costs yearly $\$ 2.06$ per passenger. Direct costs (illness, treatment and premature death) are estimated to be about US\$12 per year while the cost of the lost economic growth is much bigger (Center for Disease Control and Prevention, 2020).

\subsection{Dengue fever or Yellow fever (1971-1999, 2000-2010)}

This disease has had outbreaks in parts of the Caribbean, Central and South America, Western Pacific Islands, Australia, Southeast Asia and Africa and overall in more than 100 countries with more than 50 million of occurrences annually (Brathwaite et al. 2012). It is transmitted through mosquito bites and is also called the disease of "fractured bones", because of the relevant pain the patient feels. The disease occurrence increased enormously between 1960 and 2010, by 30 fold (WHO, 2009). This increase is believed to be due to a combination of urbanization, population growth, increased international travel, and global warming (Whitehorn and Farrar, 2010).

During the summer of 2002, Rio de Janeiro reported 288,245 cases, in 2005 Costa Rica reported 38,000 cases, while in the outbreak of 2007-2008, Brazil reported 158 deaths. Sri Lanka has reported 4,825 cases, 2 deaths in the first four weeks of 2019. Epidemic patterns occur every 3 to 5 years. Nishikawa et al. (2016) perform a literature review on the impact of dengue on tourism expenditure in Brazil in 2013. According to their scenario, a $4 \%$ decrease in tourism in Brazil (due to dengue) would cause a US\$132.3 million reduction in expenditure from international tourism and US\$1.4 billion from local tourism. No vaccine is available. The disease can be encountered only through the elimination of mosquito habitats and their bites.

\subsection{Ebola (2014)}


Ebola appeared in West Africa (Guinea, Sierra Leone and Liberia), lasted for almost three years and affected 30,000 people, with 11,325 deaths according to World Tourism Organization (2018). Tourist arrivals dropped by $50 \%$ with losses on average of $1.5 \%$ of GDP. While Ebola outbreak took place in very few countries of Western Africa, the whole Western African Continent was considered by tourists as a dangerous destination and was subject to the corresponding economic repercussions. Besides the effects on tourism, serious socioeconomic effects took over in agriculture, in private sector growth and investment. Fear for dissemination led Marroco authorities to cancel the football tournament of the African Cup of Nations (Maphanga and Henama, 2019).

\subsection{Zika virus $(2014,2016)$}

This virus has not been proved deadly, but it is rapidly spreading with more than 1.5 million people infected in Brazil. It is transferred through the "Aedes" mosquitos that have their habitats even up to the north of the USA. The virus causes mild fever and rashes, pain and headache, but it is only dangerous for women in pregnancy (Misrahi, 2016). The total impact of Zika virus on arrivals in Brazil has been obscured because of the inflated arrivals due to the Olympic games at that time.

Despite the lighter symptoms and the risk this virus bears, $64 \%$ of Americans have been reported willing to cancel their travel plans towards areas with Zika virus incidence. Forbes (2016) estimated the effects of lost tourism in the affected countries to be up to US\$63.9 billion.

\subsection{MERS-CoV: Middle East Respiratory Syndrome (2015)}

MERS-CoV broke out in May (2015) from South Korea and was initiated by an infected Korean traveler returning from the Middle East. More than 16,000 people were quarantined and 38 died (Joo et al., 2019). The Korean government at that time revised its budget upwards to US\$860 million in order to encounter MERS. As far as the impact on tourism from MERS is concerned, after the outbreak period was over, namely January to June 2016, the projected values for tourism (namely the ones adapted for the damage the virus had inflicted on tourism) were not much different from the real ones. The fact that this virus outbreak had lighter effects on the economy is also suggested in Jung and Sung (2017) who found that groceries sector received no negative impact, offline sales of electronics declined by $7.9 \%$ and online sales increased by $7.03 \%$ indicating that these two markets behaved as substitutes. Last, according to the same study semi-luxury goods demand decreased for two months only. However, MERS was known to be more fatal than SARS (Durai et al., 2005). Seoul had lost $38 \%$ of its foreign tourists during the first two weeks after the outbreak. Also, transit riders were reduced by $12 \%$ (The Seoul City Government, 2015).

\subsection{Bird flu or Avian influenza or H5N1 (1996-97, 2017)}


H5N1 is caused by viruses adapted to birds. More specifically, this virus occurs naturally among wild aquatic birds and can infect domestic poultry and other bird and animal species. Initially this virus was traced in Asia but it was later spread in Europe and Africa as well. Mortality rate was about 60\% (WHO, 2007). According to Beigel et al. (2005), the transmission from human to human is of low probability and hence it is a virus that does not affect tourism so much. Thus, the fear is about the food sources which may have been contaminated with the virus rather than other humans. Nevertheless, tourism does not go completely unaffected (Page et al., 2006). Kuo et al. (2018) have used monthly time series data from 12 most afflicted countries and regions from the Avian flu and they found that tourist arrivals would be reduced by 147-168 tourists for every new reported case of Avian flu. Asia has been more heavily hit by reduced tourism, because of public health considerations potential tourists have for these countries. People believe that the proper measures had not been taken in time in order to prevent the expansion of the disease.

\subsection{Mad cow disease or Creutzfeldt-Jakob Disease $(1986,1996,2003)$}

Humans can contract a variant of this disease which is fatal by slowly destroying the animal and human brain and spinal cord. Contraction to humans can occur by consuming special tissues from the meat of an infected animal (HealthLink BC, 2018). The first occurrence of the mad cow disease was reported in 1996. Most cases have been found in UK and Northern Ireland. In 2003 there was an incidence in Canada, but the tourism industry had already been tarnished by SARS, so another impact chronologically close would make much additional difference (Waldie, 2003; 2018). Reynolds and Balibin (2003) have carried out research on London restaurants from 1995-2000 and found that the revenue from beef items had declined. Moroever, restaurants featuring less or no beef items experienced a lower reduction in their sales. Overall, despite the fears this crisis caused, it was regarded as a more of a veterinary and food crisis rather than a total asymmetric threat, as nowadays COVID19 appears.

\subsection{H1N1 or Swine Flu (2009)}

In June 2009, World Health Organization (WHO) announced the pandemic of H1N1 with 18,500 deaths in 214 countries. This is a virus endemic in pigs and in the past it would affect people who worked close to pigs. In Mexico, hotel occupancy was $60 \%$ before the epidemic and it fell to $10 \%$ afterwards. This dramatic fall lasted for a month, but then it eased off. The fall was more pronounced in coastal resorts compared to mainland hotels. Foreign tourism dropped at higher levels (55\%-60\%) than the domestic tourism (45\%). Overall, in Mexico the Swine flu of 2009 caused a heavy but short term impact. Domestic tourism revived much sooner than international tourism and this is revealed by the rise of mainland tourism and the coastal tourism remaining at low levels. Overall, Mexico experienced a fall of about $17 \%$ of its tourism GDP, but for the whole country the fall in GDP corresponded to only $1 \%$. The world economy experienced a loss of $0.34 \%$ (Fenichel et al., 2003). 


\subsection{SARS: Severe Acute Respiratory Syndrome (2003)}

Based on World Bank estimations, SARS has cost to the global economy about $\$ 54$ billion, while a flu pandemic would cost $\$ 3$ trillion, namely $5 \%$ of global GDP. The SARS is supposed to have affected most negatively tourism (-64.31\%), worse than the Asian financial crisis of $1997(-2.54 \%)$, September $11^{\text {th }}$ attack $(-24.59 \%)$, Taiwan earthquake in $2001(-17.07 \%)$ based on claims by Jung and Sung (2017). Siu and Wong (2004) found that the impact of SARS was noted on demand rather than the supply of the economy. For China alone, the SARS in 2003 became responsible for a loss in international tourist arrivals into China of about 9.4 million and a loss of about $\$ 40$ million (World Economic Forum, 2020).

\subsection{The chronicle for COVID-19 (2019)}

COVID-19 was first identified in Wuhan territory, China in November 2019 and its incidence was communicated to WHO on $31^{\text {st }}$ December 2019. It originates from bats and was recognized to have infected humans in an open seafood and animal food market in Wuhan. It belongs to the same family of viruses causing MERS (in 2015 ) and SARS (in 2003). Its mortality rate (1\%-3.4\%) is lower than those of the MERS and SARS which reached $34 \%$ and $10 \%$ respectively. However, it is not as innocent as the seasonal flu whose mortality rate is much lower $(<0.1 \%)$. Also, COVID-19 is more contagious. The outbreak was disseminated through massive gatherings and movements of Chinese people at that time which coincided with the Chinese Lunar New Year in January 2020. The large incubation period of the virus (1 to 14 days) has as a result of its remaining invisible until the carrier (the person that has contracted it) has passed the virus to many more people.

After this short presentation of ten cases of viruses that have affected the economy and tourism in particular, the following section will focus with the impact of COVID19 on tourism.

\section{COVID-19 impact on the tourism sector}

This section consists of three sub-sections: Sub-section 3.1 provides an overview of the COVID-19 impact on economy in general, sub-section 3.2 focuses on the effects of COVI9-19 on Chinese tourism both as inbound and outbound tourism and last subsection 3.3 analyzes the effects of COVID-19 on the global tourism sector.

\subsection{The COVID-19 impact on global economy}

Since the world economy is a globalized environment nowadays, the COVID-19 outbreak in China was bound to affect the whole world. China is the centre of manufacturing production and top energy consumer. On $31^{\text {st }}$ December 2019, China notified the WHO about a virus which had hit the first victim in China already on $11^{\text {th }}$ November 2019. Because China had suffered past experience with SARS, it developed a quick reaction and shut down its factories with corresponding lockdowns and citizen home confinement. The closing of the industry has retarded 
the production chain and logistics. The restrictions imposed on citizen mobility and their home confinement has led to a reduction in the demand for goods. As a consequence of this, the Apple Inc. has announced that it will have a revenue reduction and this immediately led to a plunge in the S\&P 500 by 30 points. Borders across most countries have been locked and thus aircrafts have been grounded. The airline sector will experience a loss equal to \$25 billion. A large number of workers have lost their jobs due to quarantine measures which led their companies or factories to close and go bankrupt. The economic growth in China will plummet by $2 \%$. However, due to the interdependence of economies in a globalized reality, the impact of any slowdown in China will affect other major economies as well. Germany relies on Chinese economy in several ways, because the latter produces the machines required by German industry. China exports goods to Germany worth 93 billion $€$ in 2018. Moreover, China is the second largest importer of German cars after the USA (with German imports of cars worth 24 billion $€$ ).

Another large economy that is closely connected to the Chinese is that of the USA. China is the largest buyer of American bonds. A Chinese slow down will have an impact on large American companies. China imports goods from the USA of worth equal to $\$ 150$ billion. The American economy has some serious points to worry about such as the huge corporate debt, car loans and student loans. Interest rates are already low and additional monetary easing might not be of much use. Foremost the financial exposition of a colossal European bank, the HSBC, is quite high into Asian markets. Half of its revenue originates from Asian markets and it has suffered a loss of $\$ 883$ million only during the strikes in Hong Kong. This can possibly give an estimation of how large the damage will be due to closing down due to the COVID19. China had begun experiencing a lower annual GDP growth before the COVID-19 outbreak. In 2019 it had achieved a growth by $6.4 \%$ while in 2018 this was $6.6 \%$. Even such small percentage of economic growth reduction is not negligible for an economy such as China which has a debt equal to three times its GDP. It is probable that, due to the shutdown in Chinese industry, companies may choose to transfer their production away from China. Attention must be paid on the possibility of a stock market crash, if economic activity comes to a halt. The markets rapidly reacted and the shares of major airlines and tourism related companies have plunged.

Last, but not least, according to standard tourism satellite account structure, about $30 \%$ of the branches in which the economy consists of, relate themselves to tourism with one way or another. Besides accommodation and transport, a significant part of retail activities are also connected to tourism: department stores, fashion shops, fuels, healthcare, gifts, art and craft, footwear, jewelry etc. Because the supply chain in tourism has many ramifications throughout the economy, it is expected that COVID-19 will cause a high economic impact, particularly the longer the restrictions are in place. The increased costs for economies do not only relate to those preventing the economy to work, namely foregone revenue and income. Large costs are also incurred by defense costs such as those that include supply of heath facilities, medication, preventive measures such as masks, gloves, mosquito nets, sprays and disinfectants, expenses to travel to doctors and hospitals, lost days of work and income, lost days at school, burial expenses, lost opportunities in tourism. 


\subsection{The impact on Chinese inbound and outbound tourism}

In 2019, China received 142 million tourists, while Chinese nationals made 134 million outbound trips and 5.5 million domestic trips (Joppe, 2020). Chinese tourists are Canada's largest share of tourists with 800,000 arrivals and $\$ 2,800$ average spending per trip. At the time of the SARS outbreak, namely at 2003, while Canada suffered only 251 SARS cases with 43 deaths, the Canadian economy lost 28,000 jobs and $\$ 5.25$ million from its GDP and a tourist arrival fall of about 25\% (Joppe, 2020). Nowadays, China is the second largest economy with its GDP counting for $16 \%$ of the global one. Its international spending on tourism accounts for $20 \%$ globally. The 10 top destinations for Chinese tourists are Macao (71\%), Hong Kong (68\%), Thailand (28\%), Japan (27\%), Vietnam (32\%), Korea (31\%), Singapore (18\%), the USA (4\%), Malaysia (11\%) and Taiwan (24\%). Apparently, Chinese demand for tourism prefers staying in Asia and this is the reason that destinations outside Asia will be less affected by the reduced Chinese tourism demand. However, less resilient countries such as Vietnam or Myanmar and others will be confronted with a serious economic impact due to the damages in the Chinese market as a source for tourism.

Foremost, it is possible that Asians will feel alienated and will be stigmatized because the rest of the world will not regard them as safe tourists. This may create a separation between Orient and West at a moment that the international tourism sector aspires to gain a considerable share from that vast market.

\subsection{The COVID-19 impact on global tourism in general}

It is more than expected that COVID-19, as any other pandemic in the past, will have an immediate and severe impact on tourism business. International travel restrictions, national government measures, media coverage all cause an atmosphere of fear that keeps tourists away from hotels, restaurants, airlines and travel agencies. The period of time that this pandemic broke out coincides with the period of time that travel operators make reservations. Subsequent cancellations, particularly in countries where tourism contributes a significant percentage in their national incomes, will experience a dramatic rise in business bankruptcy and a rise in their unemployment rate.

The fear to visit places where many people gather and people of different nationalities intersect themselves with each other, will be well rooted for quite some time. For example, in Taiwan, which by the way is a country that has encountered COVID-19 with success because of its past experience, has developed a permanent culture of wearing a hygiene mask in places of large gatherings of people. Major tourism businesses such as air carriers of giant hotel businesses are currently making adaptations to reduce their damage. For example, IATA predicts a loss in passenger revenue equal to \$29.3billion, air companies are cutting flights and grant unpaid leaves to their staff, hotels close their branches in China and Pacific (Tounta, 2020). 
Tourism consumption will experience a sharp drop. This had also occurred during the outbreak of SARS (in 2003). Since people are staying home to save their health, they will mostly care about food, toiletries, medicine and domestic supplies and not about other categories of products. Small and local businesses are at highest risk, particularly those based in the countries that have been hot by the virus the hardest of all, namely Spain and Italy. Rossello et al. (2017) have used a gravity model to reach an estimation of travel related diseases on international tourist arrivals (such as Malaria, Dengue, Yellow fever and Ebola) and they have found that the elimination of such diseases would increase international tourist arrivals by 10 million and tourism expenditure by $\$ 12$ billion.

Tourism is a significant revenue source for many Asian countries. International tourism receipts constitute about $40 \%$ of GDP in Maldives and the tourism sector contributes about $10 \%$ of the GDP in Asian countries belong to the ADB (Asian Development Bank). Chinese people within a growing middle class are an important group of travelers for countries such as Thailand, Hong-Kong, Myanmar etc. Therefore travel bans and precaution measures will most probably keep each country nationals home and away from travelling of any kind. Many airlines have suspended their flights to and from China and issued relevant travel bans.

The tourism sector has experienced a growing share in global economy, despite the occasional shocks such as other viruses, terrorist attacks and the global economic crisis (UNWTO, 2020a) and has always shown sufficient rebound ability. The impact on tourism from COVID-19 will depend on the duration of the virus, as well as the precautions taken by countries which may exacerbate the phenomenon for a longer time (WEF, 2020). To avoid any unnecessary impact, measures should not be generic and under the pretext of the protection of civilians-voters. They should be specific and based on scientific evidence.

Even if the tourism sector per se was not affected, the supply-side disruptions and the logistics channels, would affect tourism. Forced business closures and the inability of people to go to work, either because of illness or because of preventive measures they take for their protection (they do not use mass transport, they do not work close with one another in their offices or place of work). Table 1 had been adapted from the Asian Development Bank (2020) and presents three scenarios of impact on tourism revenue.

Table 1. Impact on tourism revenue as percentage of GDP in the 7 worst afflicted countries

\begin{tabular}{lll}
\hline Best case & Moderate & Worst case \\
scenario & case & scenario \\
& scenario &
\end{tabular}

Country $\%$ of GDP \$ million $\%$ of GDP $\quad \$$ million $\%$ of GDP $\$$ million

$\begin{array}{lllllll}\text { Palau } & -2.918 & -8.3 & -4.376 & -12.4 & -8.753 & -24.9\end{array}$




\begin{tabular}{lllllll}
\hline & $\begin{array}{l}\text { Best case } \\
\text { scenario }\end{array}$ & \multicolumn{3}{c}{$\begin{array}{l}\text { Moderate } \\
\text { case } \\
\text { scenario }\end{array}$} & \multicolumn{3}{c}{$\begin{array}{l}\text { Worst case } \\
\text { scenario }\end{array}$} \\
Country & \% of GDP & \$ million & \% of GDP & \$ million & \% of GDP & \$ million \\
\hline Maldives & -1.839 & -98.0 & -2.758 & -147.0 & -5.517 & -293.9 \\
Cambodia & -1.409 & -345.7 & -1.929 & -473.4 & -3.490 & -856.5 \\
Hong Kong & -0.906 & -3.286 .7 & -1.178 & -4.273 .6 & -1.995 & -7.234 .1 \\
China & & -4.265 .8 & -1.224 & -6.180 .2 & -2.361 & -11.923 .5 \\
Thailand & -0.845 & -101.0 & -0.979 & -127.9 & -1.595 & -208.4 \\
Mongolia & -0.773 & -2.692 .8 & -0.941 & -3.427 .4 & -1.546 & -5.631 .3 \\
\hline Singapore & -0.739 & & & & & \\
\hline
\end{tabular}

Source: Adapted from Asian Development Bank (2020)

Based on Table 1, Palau and Maldives will be the most highly impacted Asian countries. The difference between the worst and best case scenarios in these two countries range from 4-5 percentage degrees in GDP. Since the outbreak is still under evolution, and the medical knowledge science has about this virus is scarce, we still cannot say with any confidence which of the three scenarios is most likely to apply. Even for countries such as China, which as per today $25^{\text {th }}$ March is the third consecutive day on which no new outbreak has been reported, it is too early to draw any conclusions, because the scientific community does not know whether the possibility for re-infection is there, even for people who have survived the disease once.

As far as the European countries are concerned, particularly some of them are already hit by the economic crisis and trying to get themselves out of the vicious circle of reduced aggregate demand, a further decrease in tourism could lead to the deepening of economic recession. The European Union (EU) has decided to contribute to the revival of the affected economy sectors with structural funds of $€ 37$ billion (Brzozowski, 2020). The European countries of the Mediterranean are popular tourist destinations and are also the ones most heavily impacted, particularly Italy, Spain and France. Greece has applied strict measures quite early and at the moment (as of $25^{\text {th }}$ March) has suffered the least victims from all the aforementioned Mediterranean countries.

\section{Adaptation of the tourism sector to COVID-19; Suggestions in case of future pandemic outbreaks}

According to UNWTO (2020), international tourist arrivals will decline within a range from $1 \%$ to $3 \%$ in 2020 globally, which is an equivalent to a range from 30-50 billion USD in international tourist spending. Asia and Pacific will be the most afflicted regions with a reduction between $9 \%-12 \%$. However, since the spread of the virus is still under evolution, these figures are still volatile. 
In a period of high uncertainty and risk such as this, tourism businesses should continue their advertisement campaigns, now possibly with social marketing orientations. Campaigns that contain altruistic messages such as \#staysafe, convene the message to customers that the businesses care for the benefit and security of the customer and that they do not focus solely on profit, but their first priority is to encourage customers stay safe during this period and participate in tourism later when it will be safe. Therefore, it is important for businesses to continue advertising because now the (confined at home) customer has more time to read and observe ads and needs to keep dreaming of the better days that will come. Foremost, the potential traveler must be given the opportunity to plan holidays for 2021 which is assumed to be a COVI9-19 virus free year. Furthermore, these booking opportunities should be accompanied by smart insurance programmes that give potential tourists the opportunity to hedge against such unfortunate contingencies that have now entered our lives. The customer should be awarded the freedom to cancel with no penalty when a risky situation appears and re-schedule with no additional charges.

Since tourism consists of two main components, a dynamic (transportation) and a non-dynamic (accommodation), these are the two main factors that must heavily adapt and transform to comply with serious health safety measures in order to convince people to keep traveling and going on holidays. If travelers rest assured that the means of transportation and their hotel at destination will not transmit the virus, then the traveler will be able to self isolate in holidays and enjoy a more independent style of tourism keeping all the safety measures and precautions that one would also take while at home. At a moment when mass transportation could be a preferable and sustainable solution, because it could reduce environmental problems, this is going to change in front of a risky context. Travelers will prefer to travel alone or in smaller numbers, in order to be able to keep safe distance from cotravelers which will protect them from the spreading of contagious diseases. Lower number of travelers would entail an increase in costs, which is not an option for many citizens. Traveling with protection uniforms in airplanes and careful monitoring of corporal temperature, or other virus symptoms, is a future option and could give travelers a sense of security. Keeping the middle seat vacant in aircrafts and the provision of guaranteed disinfection could be regarded with relief and encourage people to keep travelling. Foremost, tourism recipient countries should be vigilant and employ passenger screening programmes at all costs.

On the other hand, the accommodation sector is another factor that causes insecurity to tourists because of the fear of disease contraction. A hotel room is supposed to have been adequately cleaned before use by a new customer and the toilet has been disinfected. However, disinfection has assumed increased and extended dimensions in the current virus-infested days. Customers will require different and higher disinfection standards in hotel rooms. They will need to know that all possible places and niches where the previous inhabitant of the room has touched or come into contact, have been sufficiently cleaned and disinfected: Wardrobe handles, drawer handles, door handles, tele-controls, any kind of buttons and electric sockets, any kind of surfaces. Despite hotel cleaners already doing that, 
there must be proof that this has been done. Since humans can make mistakes, we need a device for electronic monitoring of the cleanness level in the hotel room. This will check all possible surfaces and places in the room and will make sure that they have been disinfected. Such a job could possibly be performed by a robot. Also, a hotel might opt for materials in the room, that are anti-bacterial by nature such as copper. Moreover, gifts and souvenirs from hotel shops or shops outside the hotel can be purchased with vouchers and delivered with no-contact drop-off modus operandi. The same can occur in restaurants and bars outside the hotel, which can be delivered to customers while in their hotel rooms. Thus, a new era begins for hotels, advertising and proving their cleanness level and the operation practices that guarantee no human contact when this is imposed by hygiene precautions.

\section{Domestic tourism will most likely be the first to recover}

It is natural to expect that people are afraid less of something that is close to their home base, because they can have a closer perception of what is happening in that. Therefore, it is assumed that future travelers will go on holidays first within their own countries until they regain confidence. This entails that hotel and holiday prices in general must be adapted for the incomes of domestic consumers and not of the international ones. Domestic travelling can be done with personal cars so people will not have to use a congested aircraft, a full ship or bus to move to their destination.

\section{The end of massive tourism}

Irrespective of whether COVID-19 will retaliate next year, or if the vaccine and appropriate medication are invented soon, massive tourism has been hit forever. Massive tourism model had changed anyway before the panic from COVID-19 had started, because nowadays travelers seek to enjoy unique experiences and they have started disliking the 1980 s or 1990 s model of all-inclusive packages. Independent tourism will completely take over, both due to an attitude change in the culture and education of the travelers, but as it has turned out, also due to safety reasons, since independent tourism will be safer. One can opt for social distancing within this form of tourism. Conversely, social distancing is not feasible when one travels in a group in organized holidays or when he stays in huge hotels where tourists find themselves together with others, in the dining room, in the swimming pool or the sports facilities and other facilities and venues organized under the massive tourism model.

\section{The transformation of conference tourism}

Conference tourism is another form of tourism which cannot be disentantagled from the co-existence and socializing with the peers. After all, that is the uppermost essence of conference tourism. Academicians or researchers and professionals combine their participation to a scientific venue with tourism. Socializing is inevitable and is also strongly sought after, because through this, scientists can exchange ideas and develop common research projects. Thus, conference tourism will have to be transformed too in front of a risky reality. Of course participating in a conference with skype or other electronic means has already been eligible in the past, the 
forthcoming conferences will have to be postponed or carried out in a completely remote way. Keeping safe distances from one another in future conferences is also feasible, if participants are seated in a safe distance from each other and seats in conference rooms are more sparsely placed. In addition to this, the socializing part of a conference can also be restricted and participants can move around in the host cities in an independent way, taking the precautions and safety measures they would take anyway, as if they were at home.

\section{Pilgrimage tourism}

Pilgrimage tourism is also a form of mass tourism, not only in the transport and accommodation dimension, but also due to the destination activities. Tourists in these cases visit sacred places, temples and places of worship that have been visited by many people from many different countries. Paying respects to holy pictures, as many Christians do, participating in mass and other venues, receiving Communion are tactics that are considered nowadays with skepticism for their health and hygiene standards. The Catholic Church, the Orthodox Church and the Islamic religion have closed churches and temples, temporarily in an attempt to put off large gatherings of people and the communal use of religious symbols.

\section{Aviation, mass transportation \& Cruise tourism}

Many air companies have cancelled or reduced flights, some have allowed temporal leaves for their staff or have allowed shorter and more flexible working timetables. Similar attitudes and solutions have been adopted by almost all means of transportation, also with regular disinfection sessions. For the means of transportation to adapt to the new reality entailed by regular disinfection schemes and by providing safe distancing to passengers from each other, would require a high increase in costs that would be mostly transferred to passengers. While the increased fare in aviation could hypothetically be borne by the customer with different yield management rules, the increased cost transportation cannot be borne by employees who use the bus or underground daily to go to work. The increased cost could most likely be shared among the passenger, the employer and the state.

\section{"Safe summer tourism only" vs the need to combat seasonality}

While the tourism sector is trying to balance seasonality in the sector and spread tourist demand throughout the year, this may not be feasible, if COVID-19 or other future virus is proved to be eliminated during high temperatures in summertime. Many international organizations, governments and other stakeholders acknowledge the damage and cost borne in the tourism sector, the environment and society through peak tourism seasons like summertime. Infrastructure is overused for a short time during the year, but it remains in a state of inertia for the rest of the year (namely winter season). The same applies for public infrastructure, the labor force and the environmental sources such as water, energy, air and landscape. Thus, while all involved parties are considering inaugurating institutional changes such as dispersing school holidays round the year and encouraging employees taking their 
paid leave in accordance with that, this cannot be pursued with safety, if viruses come to life during wintertime. The resilience of the virus in cold temperature will render winter, autumn and spring holidays riskier from this perspective. This risk could be minimized with the aforementioned hygiene and disinfection precautions suggested for aviation and the hotel sector. Furthermore, the winter holidays prices must be lower to attract sufficient demand and lure clients to try the new product.

\section{New technologies and virtual reality tourism}

New technologies are gradually gaining their place in tourism as in many other economic sectors. However, their degree of adoption varies a lot among different tourism businesses and a significant part of them regards tourism as an experience that is rendered distinct and unique only through human contact, and thus that new technologies alienate this contact. However, in situations as those we are going through with COVID-19 and other future viruses, we may have to reconsider this attitude and insert new technologies wherever they can be inserted.

Virtual reality in the tourism sector is another option that should be paid renewed attention, not in an attempt to replace real tourism, but to complement it and replace or complement realistic experiences that at times can be perilous. For example, in perilous circumstances such as the current ones with COVID-19, a tourist may be able to enjoy visits to theme parks or archaeological sites, museums and crowded places through virtual reality facilities. Or one may be able to participate in games and venues, while at a tourist destination, through that possibility and prefer to spend more time in the disinfected hotel and from that enjoy various experiences with virtual reality.

\section{Medical tourism}

Medical tourism is the tourism experience that is combined with visits to doctors at the destination or with the provision of medical care for various reasons. It is not only geriatric or silver tourism that requires a vigilant back up of medical stuff and relevant facilities. One may decide to go for relaxation tourism that offers relief from chronic pain, thermal baths and the attention of special gym or other specialized classes. This type of tourism could be developed into a sterilized environment that can guarantee high standards of hygiene and precaution form the moment the tourist leaves home to the moment one returns home again. This is a type of tourism that could lend many of its best example practices to other types of tourism and thus cope with health threatening situations as the one generated from COVID-19.

\section{Over-tourism combat and social distancing: getting two birds with one stone}

It is common knowledge that some places and regions suffer from over-tourism. This concept refers to a situation that tourist numbers are so high that they go beyond the capacity a particular place normally has. The capacity refers to the environmental and the social dimensions as well as the economic ones. Reversing over-tourism and creating social distance to prevent spreading of viruses happens to 
be at the same direction, albeit not the same thing. However, creating social distancing and imposing safety distances between tourists in crowded places will eventually mitigate the problem of over-tourism through the reduction of the tourist numbers at a time. Thus, environmental sustainability will also be promoted.

\section{Concluding remarks}

Lessons from the past, namely tourist arrival declines due to SARS IN 2003, the war in Iraq etc have shown that tourism has recovered relatively quickly (UNWTO, 2020). WHO uses as benchmark the impact of SARS and then factors the size and the dynamics of the impact of COVID-19. Nevertheless, given that COVID-19 has been contracted by many more people all over the world, and the urgent precautions that have been taken such as business shut down and containment of people at home for longer than a month's time, there are more serious repercussions from COVID-19 applying for the whole economy in general and the tourism sector in particular. With fifty million tourism jobs at risk (30 million of them in Asia), as soon as this ends, it may take ten months for tourism industry to recover (WEF, 2020). However, since we are confronted with a virus whose behavior is not known beforehand by medical community, this makes the current situation highly volatile. Therefore, repercussions will be in correspondence with the duration of precaution measures. The less optimistic claim that it may take up to twelve months before the vaccine is invented. Others claim that the virus is not resilient in hot weather and so this will provide some intermittence for the summer period. If this happens, it will give some meager opportunity for tourism revenue. However, countries must assess the feasibility of reintroduction of the COVID-19 before they deal with its elimination, since the possibility of re-infection even for people who have passed the illness once, has not been excluded by medical authorities.

According to World Health Organization (2014), 90\% of economic losses occur after uncoordinated efforts of the public to avoid infection. This makes necessary the provision of continuous, timely and accurate information so than panic is avoided and protection takes place only after official warnings. When travelers began to perceive that it is safe to travel, only then, will they attempt again that. At that time, governments must simplify visas wherever possible, but travel taxes, so that there are stronger incentives for people to travel. Also, additional flexibility in cancelling or postponing will make travelers less reluctant in buying touristic products.

All is hardship inflicted to people worldwide, equip humanity with a context for learning and teaching about aspects of risk, safety, preparation, community involvement and personal responsibility. Nations will show their solidarity to combat this lethal situation. Tourist businesses can continue their marketing strategies but this time also enriching them with social marketing messages and tools. 


\section{REFERENCES}

Asian Development Bank (2020). The economic impact of the COVID-19 outbreak on developing Asia, ADB Briefs No. 128, available from:[www.adb.org/sites/default/files/publication/571536...], accessed on $17 / 03 / 2020$

Beigel, J.H. et al.(2005).Avian influenza A (H5N1) infection in humans.The NewEngland Journal of Medicine,353,1374-1385

Brzozowski, (2020). European tourism sector urges measures to mitigate CIVID-19 impact, EURACTIVE.com, available from:[ https://www.euractiv.com/section/coronavirus/news/european-tourism-sectorurges-measures-to-mitigate-covid-19-impact/], accessed on 24/03/2020

Brathwaite Dick, O., San Martín, J. L., Montoya, R. H., del Diego, J., Zambrano, B., \& Dayan, G. H. (2012). The history of dengue outbreaks in the Americas. The American journal of tropical medicine and hygiene, 87(4), 584-593. https://doi.org/10.4269/ajtmh.2012.11-0770

Center for Disease Control and Prevention (2020). Malaria's impact worldwide, available from: [https://www.cdc.gov/malaria/malaria_worldwide/impact.html], accessed on $16 / 03 / 2020$

Durai, P.; Batool, M.; Shah, M.; Choi, S. (2015). Middle East respiratory syndrome coronavirus: Transmission, virology and therapeutic targeting to aid in outbreak control. Exp. Mol. Med. 47, e181

Fenichel, E.P.; Kuminoff, N.V.; Chowell, G. (2013). Skip the trip: Air Travelers' behavioral responses to pandemic influenza. PLoS ONE, 8, e58249.

Forbes (2016). Infographic: Zika Virus fears could cost these countries $\$ 63.9$ billion in lost tourism, available from: [www.forbes.com/sites/emilycanal/2016/02/03/zikavirus-infographic...], accessed on 17/03/2020

HealthLink BC, (2018). Mad Cow Disease, available from: [https://www.healthlinkbc.ca/health-topics/tu6533], accessed on 208/03/2020

Jonung, L.; Roeger, W. (2006). The macroeconomic effects of a pandemic in EuropeA model-based assessment. SSRN Electron. J.

Joo, H., Maskery, B.A., Berro, A.D., Rotz, L.D., Lee, Y-K., Brown, C.M. (2019). Economic impact of the 2015 MERS outbreak on the Republic of Korea's tourismrelated industries, Health Security 17(2): 100-108

Joppe, M. (2020). Trapped tourists: How is the coronavirus affecting travel?, World Economic Forum 05/02/2020, available from:[ 
https://www.weforum.org/agenda/2020/02/the-coronavirus-will-hit-the-tourismand-travel-sector-hard], accessed on 21/03/2020

Jung, E., Sung, H. (2017). The Influence of the Middle East Respiratory Syndrome Outbreak on Online and Offline Markets for Retail Sales. Sustainability 9, 411.

Kuo, H.I., Chang, C.L., Huang, B.W, Chen, C.C., McAleer, M. (2009). Estimating the Impact of Avian Flu on International Tourism Demand Using Panel Data, Tourism Economics 15(3)

Maphanga, P.M. Henama, U.S. (2019). The Tourism Impact of Ebola in Africa: Lessons on Crisis Management, African Journal of Hospitality, Tourism and Leisure, Volume 8 (3): ISSN: $2223-814 \mathrm{X}$

Misrahi, T. (2016). What does the Zika virus mean for travel? World Economic Forum, available from:[ https://www.weforum.org/agenda/2016/02/what-does-thezika-virus-mean-for-travel], accessed on 17/03/2020

Modrek, S., Gosling, J.L.R., Feachem, R.G.A. (2012). The economic benefits of malaria elimination: do they include increases in tourism? Malaria Journal 11: 244

Nishikawa, A.M., Clark, O.A., Genovez, V., Pinho, A., Durand, L. (2016). Economic impact of dengue in tourism in Brazil, Value in Health 19(3), A216

Page, S., Yeoman, I., Munro, C., Connelland, J., Walker, L. (2006). A case study of best practice-Visit Scotland's prepared response to an influenza pandemic, Tourism Management 27(3): 361-393

Reynolds, D., \& Balinbin, W. M. (2003). Mad Cow Disease: An Empirical Investigation of Restaurant Strategies and Consumer Response. Journal of Hospitality \& Tourism Research, 27(3), 358-368.

Rossello, J., Santana-Gallego, M., Awan, W. (2017). Infectious disease risk and international tourism demand, Health Policy and Planning 32 (4): 538-548

Siu, A.; Wong, Y.R. Economic impact of SARS: The case of Hong Kong. Asian Econ. Pap. 2004, 3, 62-83.

Tatarsky, A., Aboobakar, S., Cohen, JM, Gopee, N. Bheecarry, A.,Moonasar,D., Phillips, AA., Kahn, JG, Moonen, B., Smith, DL., Sabot, O. (2011). Preventing the reintroduction of Malaria in Mauritius: A programming and financial assessment: PLoS One 6(9): e23832. doi:10.1371/journal.pone.0023832

The Seoul City Government (2015). White Paper for Prevention on the Middle East Respiratory Syndrome Coronavirus; Seoul city: Seoul, Korea

Tounta, P. (2020). Pandemic 2020: The impact on tourism and the shadowy points, TravelDailyNews

03/03/2020, available 
from:[www.traveldailynews.com/post/pandemic-2020-the-impact-on-tourism-andthe-shadowy-points], accessed on 18/03/2020

UNWTO, (2020a). COVI-19: Putting people first, Update: 17/03/2020, available from: [https://www.unwto.org/tourism-covid-19-coronavirus], accessed on 24/03/2020

UNWTO, (2020b). Impact assessment of the COVI-19 outbreak on international tourism, available from: [www.unwto.org/impact-assessment-of-the-covid-19outbreak-on-international-tourism], accessed on 22/03/2020

Villanueva, E.T. (2009). Sectorial Observatory, Mexico, The impact of swine flu on tourism, available from: [https://www.bbvaresearch.com/wpcontent/uploads/mult/090623 ObserSectorialMexico 2 eng tcm348-197001.pdf], accessed on $18 / 03 / 2020$

Waldie, P. (2003; 2018). Tourism industry fears mad-cow fallout, available from: [https://www.theglobeandmail.com/report-on-business/tourism-industry-fearsmad-cow-fallout/article1015872], accessed on: 20/03/2020

WEF (2020). This is how coronavirus could affect the travel and tourism industry, available from: [https://www.weforum.org/agenda/2020/03/world-travelcoronavirus-covid19-jobs-pandemic-tourism-aviation], accessed on 24/03/2020

Whitehorn, J., Farrar, J. (2010). Dengue, Br Med Bull. 95: 161-173.

World Travel \& Tourism Council (2018). Impact of the Embola Epidemic on Travel and Tourism, available from: [https://www.wttc.org//media/files/reports/2018/impact-of-the-ebola-epidemic-on-travel-andtourism.pdf], accessed on 17/03/2020

WHO (2007). Cumulative Number of Confirmed Human Cases of Avian InfluenzaA/(H5N1) Reported to WHO, available from:[ http://www.who.int/csr/disease/avian influenza/country/cases table 200706 29/ en/index.html], accessed on 20/03/2020

WHO (2009). Dengue, guidelines for diagnosis, treatment, prevention and control, New edition, available from: [https://www.who.int/tdr/publications/documents/dengue-diagnosis.pdf], accessed on $27 / 03 / 2020$

WHO (2014). WHO Director-General's speech to the Regional Committee for the Western Pacific, available from: [https://www.who.int/dg/speeches/2014/regionalcommittee-western-pacific/en/], accessed on 27/03/2020 